\title{
Water and sediment quality at mussel (Unionidae) habitats in the Ochlockonee River of Florida and Georgia
}

\author{
Jon M. Hemming ${ }^{1, *}$, Parley V. Winger ${ }^{2}$, Steven J. Herrington ${ }^{3}$, Wendy Gierhart ${ }^{1}$, \\ Holly Herod $^{4}$, Jerry Ziewitz ${ }^{1}$
}

${ }^{1}$ US Fish and Wildlife Service, Division of Ecological Services, 1601 Balboa Avenue, Panama City, Florida 32405, USA

${ }^{2}$ US Geological Survey, Patuxent Wildlife Research Center Athens, Warnell School of Forest Resources, University of Georgia, Athens, Georgia 30602, USA

${ }^{3}$ The Nature Conservancy, Northwest Florida Program, PO Box 393, Bristol, Florida 32321, USA

${ }^{4}$ US Fish and Wildlife Service, Fisheries Resource Office, 1601 Balboa Avenue, Panama City, Florida 32405, USA

\begin{abstract}
Water chemical analyses, porewater and whole sediment chemical analyses, and porewater and whole sediment toxicity testing were performed as part of a combined effort between the US Fish and Wildlife Service and the US Geological Survey. These analyses were used to predict impaired stream sites that may impede a healthy natural riverine community. The analyses also revealed differences between sites that currently support and those that have ceased to support mussel populations. We estimated risk scores for the riverine community based on water and sediment characteristics. To identify and rank habitat in need of restoration, the risk estimation was derived by comparing collected data to water quality standards, sediment quality guidelines and toxicity test controls. High-risk scores often coincided with areas that no longer support historical freshwater mussel populations. Based on the data collected, factors thought to impede the existence of a natural riverine community included: sediment toxicity (porewater and whole sediment), sediment lead, sediment manganese, sediment ammonia, and low dissolved oxygen.
\end{abstract}

KEY WORDS: Water quality $\cdot$ Sediment quality $\cdot$ Ochlockonee River $\cdot$ Freshwater mussels $\cdot$ Unionidae

\section{INTRODUCTION}

Freshwater mussels (Unionidae) can have a large influence on total benthic biomass and are important participants in nutrient cycling and sediment dynamics in aquatic ecosystems (Newton 2003). However, both mussel abundance and species diversity in North America have declined considerably during the past century (Newton 2003). Unionid mussels are among the most rapidly declining faunal groups in the United States (Williams et al. 1993, Neves 1997). However, most studies that have reported mussel declines are based largely on anecdotal evidence of casual mechanisms (Newton et al. 2003).

Numerous causal factors for unionid declines have been reported including sedimentation, disease, pre- dation, changes in fish communities (which serve as larval hosts), alterations of river channels, commercial exploitation, environmental contamination, and introduction of exotic species (Fuller 1974, Havlik \& Marking 1987, Bogan 1993, NNMCC 1998, Augspurger et al. 2003, Mummert et al. 2003, Newton 2003). Freshwater mussel experts often report chemical contaminants as factors that may limit the survival and distribution of unionids (Richter et al. 1997, Augspurger et al. 2003). Reports of localized mortality have been attributed to chemical spills and other discrete point source discharges; however, wide-range decreases in mussel abundance and diversity may have resulted from chronic, low-level contamination (Naimo 1995, Newton 2003, Newton et al. 2003). Differential sensitivity of freshwater mussels results in tolerances to some 
organic solvents and pesticides (Keller 1993, Keller \& Ruessler 1997), but may also result in high sensitivity of early life stages to contaminants such as chlorine (Goudreau et al. 1993), metals (Keller \& Zam 1991, Jacobson et al. 1993) and ammonia (Horne \& McIntosh 1979, Goudreau et al. 1993).

Historically, the eastern Gulf Slope streams and rivers were known to have rich mussel populations. The eastern Gulf Slope streams that drain the Apalachicolan Region extend from the Escambia River on the west to the Suwannee River system. These drainages include portions of southeast Alabama, west-central and southwest Georgia, and north Florida (Florida Department of Environmental Protection [FDEP] 2001, Georgia Department of Natural Resources [GDNR] 2002).

Collectively, these rivers form a dominant drainage area in the eastern Gulf Coastal Plain (FDEP 2001, GDNR 2002). Within the eastern Gulf Slope drainage, the Ochlockonee River headwaters originate in Georgia's Worth County and the river flows in a southwesterly direction into the Big Bend region of northwestern Florida. The drainage eventually empties into the Gulf of Mexico. The Ochlockonee River basin drains approximately 6330 square miles with approximately 1460 square miles in Georgia (FDEP 2001, GDNR 2002). Much of the watershed remains relatively unmodified. Over one third of the basin area is in conservation. However, urban development, agriculture, and other anthropogenic alterations are evident, particularly in the northern watershed.

The focus of the present study was the chemical integrity of mussel habitat in the Ochlockonee River. This river provides important habitat for 3 federally listed endangered mussels, the Ochlockonee moccasinshell Medionidus simpsonianus Walker, 1905, oval pigtoe Pleurobema pyriforme Lea, 1857, and shinyrayed pocketbook Lampsilis subangulata Lea, 1840, and one federally listed threatened freshwater mussel, the purple bankclimber Elliptoideus sloatianus Lea, 1840. Like many unionids, they have declined in range and abundance in recent years as shown in surveys (Figs. 1 \& 2, USFWS freshwater mussel database unpubl. data). Much of these declines were observed after 1990 in the Little River tributary and more recently in the upper Ochlockonee River in southeastern Georgia.

During our study, 2 factors and 3 tasks were addressed from the 'Recovery Plan for Endangered Fat Threeridge (Amblema neislerii), Shinyrayed Pocketbook (Lampsilis subangulata), Gulf Moccasinshell (Medionidus penicillatus), Ochlockonee Moccasinshell (Medionidus simpsonianus), and Oval Pigtoe (Pleurobema pyriforme); and Threatened Chipola Slabshell (Elliptio chipolaensis), and Purple Bankclimber (Ellip-

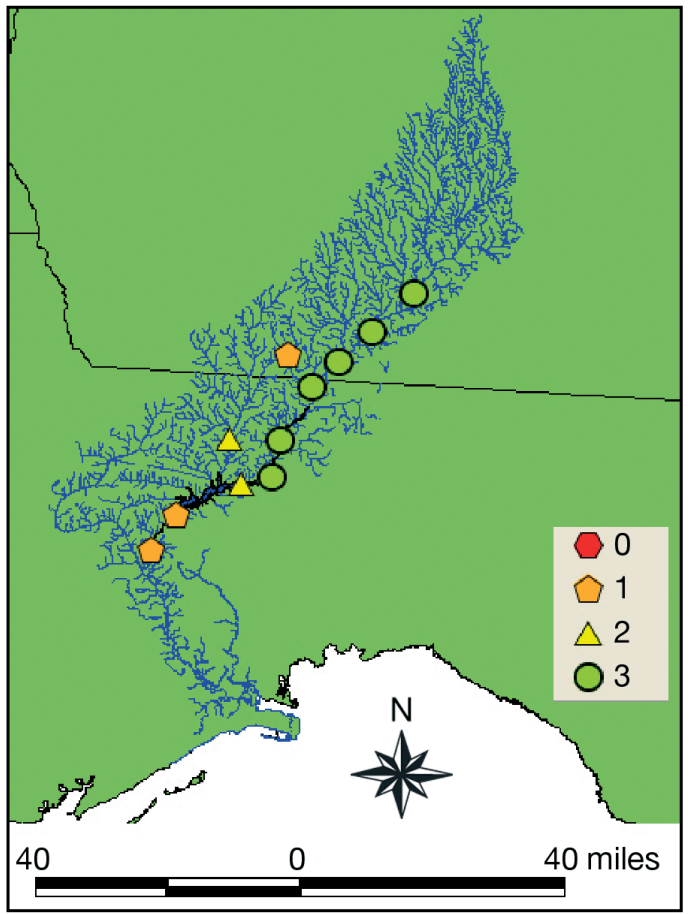

Fig. 1. Species richness (\# of different species) for federally listed threatened and endangered species of freshwater mussels in the Ochlockonee River prior to 1990 (USFWS freshwater mussel database)

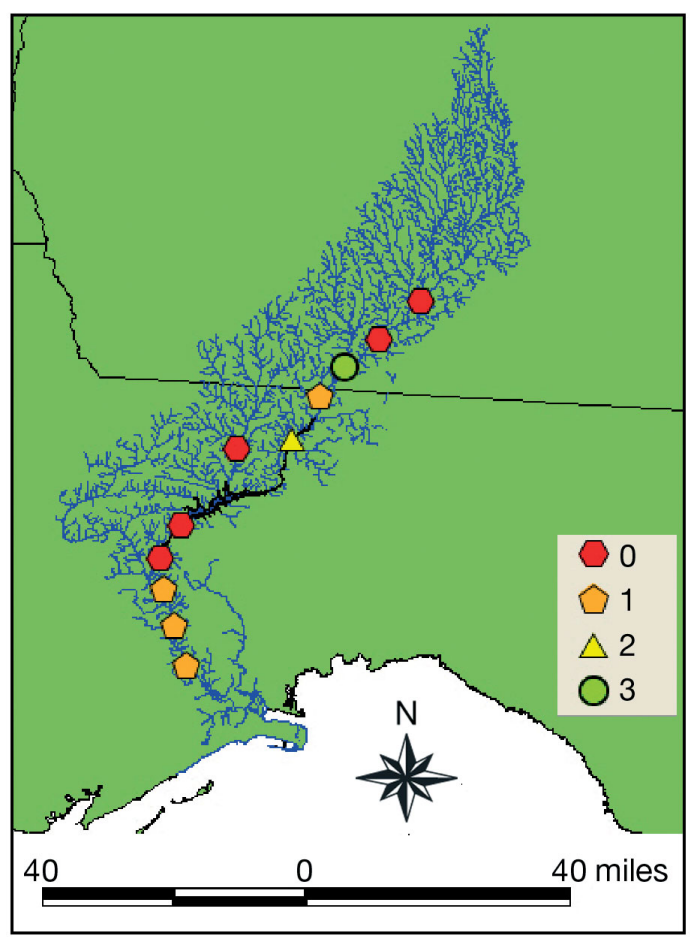

Fig. 2. Species richness (\# of different species) for federally listed threatened and endangered species of freshwater mussels in the Ochlockonee River from 2000 to 2004 (USFWS freshwater mussel database) 
toideus sloatianus)' (USFWS 2003). The goal of this study was to aid the recovery effort for these mussels by examining factors potentially affecting their continued existence, impacts of present threats, habitat improvement needs, and protection from further threats. To address these points, information on water and sediment quality was gathered and used to rank sites needing protection, restoration, and/or eventual reintroduction of listed mussel species.

\section{MATERIALS AND METHODS}

Water quality. Water quality was characterized for 12 sites along the Ochlockonee River in southern Georgia and the Florida panhandle: 6 upstream and 6 downstream of Lake Talquin (Fig. 3). Sites were selected to correspond with historical mussel survey locations (see Fig. 2). The sampling plan specified that water column grab samples be taken from each site during high water, low water and mean water discharge. Sampling was conducted during the $2004 \mathrm{cal}-$ endar year.

Water quality parameters included free copper $\left(\mu \mathrm{g} \mathrm{l}^{-1}\right)$, unionized ammonia $\left(\mathrm{mg} \mathrm{l}^{-1}\right)$, dissolved oxygen $\left(\mathrm{mg} \mathrm{l}^{-1}\right)$, temperature $\left({ }^{\circ} \mathrm{C}\right), \mathrm{pH}(\mathrm{SU})$, chlorophyll a concentration $\left(\mu \mathrm{g} \mathrm{l}^{-1}\right)$ as calculated from fluorescence, turbidity (NTU), specific conductance $\left(\mu \mathrm{S} \mathrm{cm}^{-1} @ 25^{\circ} \mathrm{C}\right)$,

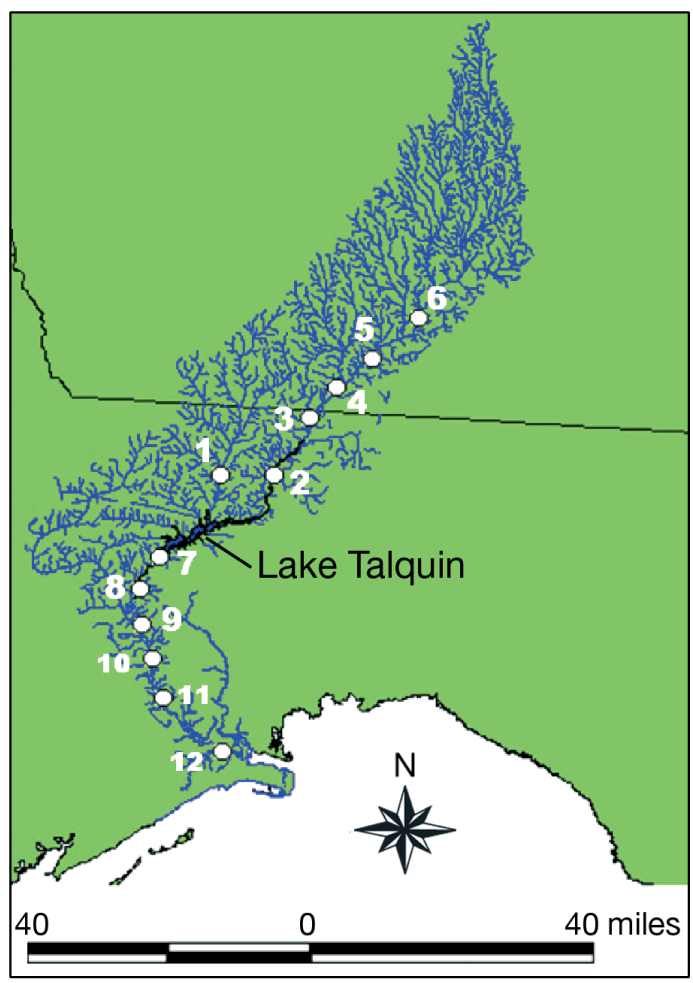

Fig. 3. Locations of USFWS water quality sampling sites (white circles) on the Ochlockonee River 2004 alkalinity ( $\mathrm{mg} \mathrm{CaCO} \mathrm{Ca}^{-1}$ ), and hardness $\left(\mathrm{mg} \mathrm{CaCO} \mathrm{Ca}_{3}\right.$ $\mathrm{l}^{-1}$ ). Dissolved oxygen, temperature, conductivity, $\mathrm{pH}$, chlorophyll concentration and turbidity were monitored in the field using a YSI Model 6600 multiparameter data logger. The instrument included a rapid pulse dissolved oxygen probe, conductivity/temperature probe, fluorescence derived chlorophyll probe, nephlometric turbidity probe, $\mathrm{pH}$ probe and calculated salinity and total dissolved solids. Readings were taken 15 to $30 \mathrm{~cm}$ from the river bottom at each site. The data were recorded to a YSI 650 multiparameter display system. The remaining analyses were performed on aliquots from $1 \mathrm{l}$ samples taken at each site. Total copper and ammonia were measured with the $\mathrm{HACH}$ DR/2400 portable lab spectrophotometer and alkalinity and hardness were measured in the laboratory with a HACH digital titrator Model 16900. Protocols for sample collection, preservation, and holding times followed American Public Health Association (1998) or HACH Company guidance.

Sediment quality. Laboratory sediment toxicity tests were performed on samples collected during August 2004 from the same 12 sites along the Ochlockonee River. Multiple sediment samples ( $\mathrm{n}=3$ to 6 ), collected at each site using a post-hole digger $(10$ to $15 \mathrm{~cm}$ depth), were combined and homogenized in $4 \mathrm{l}$ opaque, high density plastic screw-top containers. Sediment samples were held on ice while in the field and then placed on reusable synthetic ice for transport and shipment to the US Geological Survey Patuxent Wildlife Research Center's laboratory in Athens, Georgia. Samples were stored for less than $72 \mathrm{~h}$ in the dark at $4^{\circ} \mathrm{C}$ pending analyses. Laboratory assessments included toxicity testing, chemical analyses and physical sediment characterization. Toxicity testing with Hyalella azteca Saussure (Crustacea, Amphipoda) followed established protocols (US Environmental Protection Agency 1994, 2000) and included the $28 \mathrm{~d}$ chronic toxicity tests (static renewal) on solid-phase sediments, as well as acute $96 \mathrm{~h}$ static tests on sediment porewaters. Toxicity of dichloromethane extracts of the sediments were determined by exposing Vibrio fischeri (photo-luminescent bacteria, strain NRRL B11177 ) for 5 and $15 \mathrm{~min}$ exposures following procedures described for the basic test by Microbics Corporation (1992). Sediment characterization included percent moisture, percent organic matter, acid volatile sulfides/simultaneously extracted metals, and particle size analysis, in addition to analyses of trace elements from the sediment and porewater.

Prior to laboratory analyses, sediment samples were re-homogenized, and aliquots were removed to measure particle size distribution, acid-volatile sulfides (AVS), simultaneously extracted metals (SEM), percent moisture, percent organic matter, and Microtox 
bioassays. Five replicates of each field-collected sediment sample, the laboratory-control sediment (commercial sand that was washed and held in test water for $2 \mathrm{wk}$ prior to use) and a laboratory reference sample (sediments collected from Lake Lanier of the Chattahocchee River Drainage in northern Georgia) were prepared for solid-phase toxicity testing. For each replicate, $100 \mathrm{ml}$ of bulk sediment were transferred into a $300 \mathrm{ml}$ tall-form beaker with a stainless-steel mesh-covered notch. The sediment in each beaker was then covered with $175 \mathrm{ml}$ of reconstituted water (described below).

Sediment toxicity tests: Solid-phase sediments were tested under static renewal procedures (US Environmental Protection Agency 1994, 2000), with 2 renewals (70\% replacement of overlying water with each renewal) daily (Zumwalt et al. 1994). Deionized water reconstituted to a hardness of $100 \mathrm{mg} \mathrm{l}^{-1}$, alkalinity of $70 \mathrm{mg} \mathrm{l}^{-1}, \mathrm{pH}$ of 8 and conductivity of $350 \mu \mathrm{S} \mathrm{cm}^{-1}$ was used as the overlying and renewal water. Ten $7 \mathrm{~d}$ old Hyalella azteca were placed into each of the 5 replicate solid-phase test chambers. The animals were fed

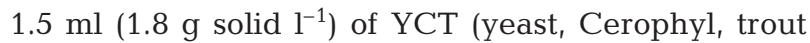
chow) daily during the $28 \mathrm{~d}$ exposure period. Temperature during the test was maintained at $23 \pm 1^{\circ} \mathrm{C}$ and the photoperiod was 16:8 h light:dark. Survival and growth (total length) were the test endpoints. Overlying water chemistry was measured in the exposure chambers at the start and end of the test and included: dissolved oxygen, temperature, $\mathrm{pH}$, alkalinity, hardness, conductivity and ammonia. Temperature, dissolved oxygen, $\mathrm{pH}$ and conductivity were monitored at periodic intervals (generally every other day) during the tests. Dissolved oxygen, temperature, $\mathrm{pH}$, conductivity and ammonia were measured with the appropriate meters and electrodes, and alkalinity and hardness were determined by titration. For the Microtox bioassays, organic extractions of the sediments were performed using dichloromethane. The moisture content of each sediment sample was determined for later calculation of sediment dry weight used in the extraction process. Approximately $5 \mathrm{~g}$ of wet sediment were mixed with sodium sulfate $(15 \mathrm{~g})$ and then $30 \mathrm{ml}$ of dichloromethane was added and thoroughly mixed. This mixture was centrifuged and the extract decanted into a flask. This extraction process (additional $30 \mathrm{ml}$ of dichloromethane, mixing, and centrifugation) was repeated 2 more times with the resulting supernatant extract being transferred to the flask. The combined extracts in the flask were concentrated to a volume of approximately $2 \mathrm{ml}$ using steam. Acetone $(5 \mathrm{ml})$ was then mixed with the extract and re-concentrated to $1 \mathrm{ml}$. This step was repeated again. Dimethylsulfoxide (DMSO) was added to make a final volume of $10 \mathrm{ml}$. A negative control was prepared using DMSO, the test carrier solvent. A positive control was prepared by adding phenol (50 $\mathrm{mg} \mathrm{ml}^{-1}$ ) to an extraction blank.

The Microtox bioassays were conducted using the Microtox Toxicity Analyzer System following protocols described by Microbics Corporation (1992). Freezedried Vibrio fischeri bacteria and reagents were obtained from Microbics (now marketed by Strategic Diagnostic). Sediment extracts were tested following the procedures described under 'Condensed Protocol for Basic Test, Using Organic Solvent Sample Solubilization' (Microbics Corporation 1992). The amount of light lost was proportional to the toxicity of the test sample. The concentration of the extract that inhibited luminescence of $V$. fischeri by $50 \%$ after a 5 and $15 \mathrm{~min}$ exposure represented the EC50 values as mg equivalent sediment wet weight. The wet-weight EC50 values were converted to EC50 dry-weight values for reporting purposes and comparison with other data. The tests were performed in 3 replicates.

Sediment porewater toxicity: Porewater samples (filtered through a $0.45 \mu \mathrm{m}$ filter) for toxicity testing and chemical analyses were extracted from the remaining sediment from each sample using a vacuum extractor consisting of a fused glass air stone, airline tubing and a 60 cc syringe (Winger et al. 1998). Approximately $300 \mathrm{ml}$ of porewater were obtained from each sediment sample, aerated for 15 min (dissolved oxygen concentrations exceeded saturation levels during the test), and then $20 \mathrm{ml}$ were transferred to each of 5 replicate $30 \mathrm{ml}$ plastic cups. Ten $7 \mathrm{~d}$ old Hyalella azteca and a $1 \mathrm{~cm}^{2}$ piece of Nitex ${ }^{\circledR}$ netting $(275 \mu \mathrm{m})$ were placed into each cup. H. azteca were exposed to porewater for $96 \mathrm{~h}$ under static conditions and were not fed during the test. The test exposures were maintained at $23 \pm 1{ }^{\circ} \mathrm{C}$ and $16: 8 \mathrm{~h}$ light:dark photoperiod. The endpoint of the porewater test was survival. Water characteristics (temperature, dissolved oxygen, pH, alkalinity, hardness, conductivity and ammonia) were measured at the start of the test in porewater after aeration.

Sediment analyses: After digestion with hydrochloric acid and nitric acid, concentrations of $\mathrm{Al}, \mathrm{As}, \mathrm{Cd}, \mathrm{Cr}$, $\mathrm{Cu}, \mathrm{Fe}, \mathrm{Mg}, \mathrm{Mn}, \mathrm{Mo}, \mathrm{Ni}, \mathrm{S}, \mathrm{Pb}$ and $\mathrm{Zn}$ were measured in the sediment with a Perkin-Elmer Plasma II sequential inductively coupled plasma emission spectrometer. After digestion with nitric acid and hydrogen peroxide, As and Se in sediments were measured using a PerkinElmer Zeeman Model 3030 graphite furnace. Acid volatile sulfides (AVS) were determined following methods described by Brouwer \& Murphy (1994). Cations in pore water and metals included in the simultaneously extracted metals (SEM: Cu, Cd, Sn, $\mathrm{Hg}, \mathrm{Pb}, \mathrm{Zn}$ ) were measured using a Perkin Elmer Elan 6000 ICP-MS (inductively coupled plasma emissions mass spectrometer). Anions (chloride, sulfate, and 
nitrate) in pore water were determined using an ion chromatograph. Sediment particle size distribution was determined using procedures described by Miller \& Miller (1987). Percent moisture was measured as the difference between original wet weight and that after drying for $24 \mathrm{~h}$ at $105^{\circ} \mathrm{C}$. Percent organic matter was derived by loss on ignition at $450^{\circ} \mathrm{C}$ for $4 \mathrm{~h}$ (Davies 1974).

Statistical analyses on sediment toxicity tests: Statistical analyses were conducted using Statistical Analysis Systems (SAS Version 6, 1990). Comparisons among sites and the control were conducted for survival in porewater and survival and length from solidphase sediments of Hyalella azteca. These test endpoints were compared (simple deterministic risk assessment) to water and sediment chemistry and metal concentrations in pore water and solid-phase sediments; analysis of variance using General Linear Models and Dunnett's one-tailed test for significant differences in length and survival in comparison to the control. Statistically significant differences were accepted at $\alpha=0.05$. Similar analyses were performed on the Microtox data. EC50 values from sediment extract testing using Microtox bioassays were compared with test endpoints from the $H$. azteca tests and trace element analyses from porewater and sediments. Analyses were performed on log-transformed data due to the typical sigmoidal dose-response relationships observed.

Evaluation of potential risk and land use analysis. Risk estimation associated with water and sediment quality was performed for the individual habitat integrity categories of water chemical quality, sediment toxicity, and sediment chemical quality. One point was assigned to a site for every observed instance of the following: (1) an exceedance of state water quality standards or federal water quality criteria, (2) when toxicity was observed, or (3) sediment quality guidelines were exceeded. The points were then summed by site to achieve a total assessment.

To identify potential stressors, water and sediment quality results were compared to permitted point source discharges (via National Pollution Discharge Elimination System Permits), general land use characterizations provided by the respective state water management authorities, and the current and historic presence/absence data for freshwater mussels in the Ochlockonee River drainage. Additionally, data were evaluated relative to State of Florida water quality standards for the protection of aquatic life, Environmental Protection Agency water quality criteria for aquatic life protection, and to information generated by ongoing multi-regional and multi-agency efforts to better estimate toxicity thresholds for these taxa. However, information is currently insufficient to assess risk to these species from water quality in the targeted watersheds. Therefore, Geographic Information System (GIS) layers of relative water quality and estimated species risk per location were developed to provide a comparative visual tool to better assess watershed conditions. This assessment allowed ranking of sites for a better understanding of relative risk.

\section{RESULTS AND DISCUSSION}

Water quality

Water quality data were recorded at 12 sites on the Ochlockonee River, but not under all flow conditions intended (Table 1). As a result of the onset of persistent high river flows, 1 low flow and 2 high flow events were monitored during the study timeframe. Mean monthly flow conditions $\left(\mathrm{m}^{3} \mathrm{~s}^{-1}\right)$ for each sampling event were 27, 21, and 12 for sites upstream of Lake Talquin and 65, 93, and 34 for sites downstream of Lake Talquin, respectively, according to USGS gaging stations for the months of June, July and August. Extensive rainfall precluded sampling under low flow conditions again or under mean flow conditions.

Total ammonia concentrations in the Ochlockonee River system were relatively low $\left(0.02\right.$ to $0.1 \mathrm{mg} \mathrm{l}^{-1}$ total ammonia as $\mathrm{N}$ at $\mathrm{pH}$ 8) compared to the recommended range for a criteria continuous concentration (CCC, 0.3 to $1.0 \mathrm{mg} \mathrm{l}^{-1}$ total ammonia as $\mathrm{N}$ at $\mathrm{pH}$ 8) by Augspurger et al. (2003) and the State of Florida ammonia water quality standard $\left(0.4 \mathrm{mg} \mathrm{l}^{-1}\right.$ total ammonia as $\mathrm{N}$ at $\mathrm{pH}$ 8). For both of the above reference values the free ammonia concentration was maintained, while the total ammonia concentration was adjusted to the recorded maximum system $\mathrm{pH}$ of 7.3 and $25^{\circ} \mathrm{C}$. Based on the recommended criteria and the water quality standard, the risk to aquatic species from ammonia exposure was expected to be low in ambient water. This low expected risk was supported after examining the influence of the system's low pH (6.2 to 7.3) via the calculation of unionized ammonia concentrations. The lower the aqueous $\mathrm{pH}$, the larger the proportion of the ammonia species that are ionized $\left(\mathrm{NH}_{4}^{+}\right)$. The higher the $\mathrm{pH}$, the larger the proportion of ammonia species that are un-ionized ammonia $\left(\mathrm{NH}_{3}\right)$. The low $\mathrm{pH}$ condition was a direct reflection of the low buffering capacity or alkalinity (6 to $19 \mathrm{mg} \mathrm{CaCO}_{3} \mathrm{l}^{-1}$ ) in the system.

Free copper concentrations also were quite low at our study locations in the Ochlockonee River system. Copper was detected only twice at 2 and $3 \mu \mathrm{g} \mathrm{l}^{-1}$. Because low system hardness (measured as $\mathrm{mg} \mathrm{l}^{-1}$ $\mathrm{CaCo}_{3}$ ) resulted in very low State standard or USEPA (US Environmental Protection Agency) water quality criterion calculations $\left(2.75 \mu \mathrm{g}^{-1}\right.$ and $2.64 \mu \mathrm{g} \mathrm{l}^{-1}$ free 
Table 1. Water chemistry of grab samples taken at various flows ( $\mathrm{Fl} ; \mathrm{H}=$ high flow, $\mathrm{L}=\mathrm{low}$ flow) in the Ochlockonee River, summer 2004, compared to Florida Department of Environmental Protection (DEP) water quality standards and US Environmental Protection Agency (USEPA) water quality criteria. N.A. = data not available, ND = analyte not detected within the range of the method used

\begin{tabular}{|c|c|c|c|c|c|c|c|c|c|c|c|}
\hline Site & $\mathrm{Fl}$ & $\begin{array}{c}\text { Total } \\
\mathrm{NH}_{3} \\
\left(\mathrm{mg} \mathrm{l}^{-1}\right)\end{array}$ & $\mathrm{pH}$ & $\begin{array}{l}\text { Alkalinity } \\
\left(\mathrm{mg} \mathrm{CaCO}_{3}\right)\end{array}$ & $\begin{array}{l}\text { Dissolved } \\
\text { copper } \\
\left(\mu g l^{-1}\right)\end{array}$ & $\begin{array}{c}\text { Hardness } \\
\left(\mathrm{mg} \mathrm{CaCO}_{3}\right)\end{array}$ & $\begin{array}{l}\text { Dissolved } \\
\text { oxygen } \\
\left(\mathrm{mg} \mathrm{l}^{-1}\right)\end{array}$ & $\begin{array}{l}\text { Water } \\
\text { temp. } \\
\left({ }^{\circ} \mathrm{C}\right)\end{array}$ & $\begin{array}{l}\text { Turbidity } \\
\text { (NTUs) }\end{array}$ & $\begin{array}{l}\text { Chlorophyll a } \\
\qquad\left(\mu g ~^{-1}\right)\end{array}$ & $\begin{array}{c}\text { Specific } \\
\text { conductance } \\
\left(\mu \mathrm{S} \mathrm{cm}^{-3} @ 25^{\circ} \mathrm{C}\right)\end{array}$ \\
\hline \multirow[t]{3}{*}{1} & $\mathrm{H}$ & 0.322 & 7.1 & 19 & ND & 27 & 7.4 & 26.0 & 15.3 & N.A. & 87 \\
\hline & $\mathrm{H}$ & 0.42 & 7.3 & 16 & ND & 24.5 & 7.7 & 25.6 & 17.3 & 5.4 & 88 \\
\hline & $\mathrm{L}$ & 0.0328 & 7.1 & 11.4 & ND & 23 & 8.0 & 26.1 & 14.4 & 5.3 & 89 \\
\hline \multirow[t]{3}{*}{2} & $\mathrm{H}$ & 0.325 & 6.3 & 7 & ND & 18 & 6.0 & 27.0 & 30.3 & N.A. & 57 \\
\hline & $\mathrm{H}$ & 0.094 & 6.5 & 17 & ND & 26.4 & 5.1 & 28.2 & 17 & 7.6 & 78 \\
\hline & $\mathrm{L}$ & 0.0622 & 6.9 & 14.4 & ND & 23.8 & 7.2 & 27.2 & 16.5 & 6.2 & 97 \\
\hline \multirow[t]{3}{*}{3} & $\mathrm{H}$ & 0.349 & 6.2 & 6 & ND & 15 & 5.4 & 26.6 & 24.7 & N.A. & 59 \\
\hline & $\mathrm{H}$ & 0.1297 & 6.5 & 18 & ND & 26.4 & 4.5 & 27.9 & 18.5 & 7.4 & 84 \\
\hline & $\mathrm{L}$ & 0.0558 & 6.7 & 15.7 & ND & 26.5 & 6.6 & 27.3 & 15.7 & 6.8 & 87 \\
\hline \multirow[t]{3}{*}{4} & $\mathrm{H}$ & 0.352 & 6.3 & 9 & ND & 18 & 5.4 & 26.6 & 22.8 & N.A. & 67 \\
\hline & $\mathrm{H}$ & 0.1637 & 6.5 & 17 & ND & 26.2 & 4.6 & 27.7 & 17.3 & 6.8 & 87 \\
\hline & $\mathrm{L}$ & 0.0536 & 6.7 & 15.3 & ND & 26.1 & 6.5 & 26.9 & 17.4 & 6.3 & 93 \\
\hline \multirow[t]{3}{*}{5} & $\mathrm{H}$ & 0.376 & 6.3 & 10 & 3.0 & 21 & 5.3 & 27 & 35.8 & N.A. & 71 \\
\hline & $\mathrm{H}$ & 0.134 & 6.5 & 16 & ND & 26.8 & 4.9 & 27.5 & 15 & 6.2 & 84 \\
\hline & $\mathrm{L}$ & 0.0438 & 6.6 & 18.7 & ND & 31.4 & 6.3 & 26.4 & 16.1 & 0.6 & 83 \\
\hline \multirow[t]{3}{*}{6} & $\mathrm{H}$ & 0.368 & 6.6 & 16 & ND & 28 & 6.0 & 26.1 & 11 & N.A. & 87 \\
\hline & $\mathrm{H}$ & 0.248 & 6.8 & 10 & ND & 29.1 & 6.7 & 26.2 & 10.1 & 2.5 & 72 \\
\hline & $\mathrm{L}$ & 0.0571 & 6.7 & 20.4 & ND & 26.7 & 7.1 & 25.2 & 49.3 & 6.1 & 66 \\
\hline \multirow[t]{3}{*}{7} & $\mathrm{H}$ & 0.26 & 6.9 & 20 & ND & 26 & 4.3 & 28.2 & 1.9 & N.A. & 83 \\
\hline & $\mathrm{H}$ & 0.286 & 6.6 & 18 & ND & 25 & 2.3 & 29.5 & 6.7 & 11.0 & 79 \\
\hline & $\mathrm{L}$ & 0.0509 & 6.6 & 13.9 & ND & 22.3 & 3.0 & 28.8 & 2.7 & 10.0 & 74 \\
\hline \multirow[t]{3}{*}{8} & $\mathrm{H}$ & 0.248 & 6.7 & 17 & ND & 17 & 5.0 & 27.1 & 1.9 & N.A. & 75 \\
\hline & $\mathrm{H}$ & 0.458 & 6.6 & 18 & ND & 25 & 4.5 & 28.9 & 6.6 & 10.7 & 76 \\
\hline & $\mathrm{L}$ & 0.0935 & 6.7 & 13.5 & ND & 22.8 & 5.8 & 28.6 & 2.5 & 8.0 & 72 \\
\hline \multirow[t]{3}{*}{9} & $\mathrm{H}$ & 0.256 & 6.7 & 18 & ND & 18 & 4.3 & 27.2 & 9.7 & N.A. & 77 \\
\hline & $\mathrm{H}$ & 0.378 & 6.7 & 19 & ND & 24.6 & 3.8 & 29.2 & 6.2 & 10.2 & 77 \\
\hline & $\mathrm{L}$ & 0.105 & 6.6 & 13.8 & ND & 21.6 & 5.0 & 29 & 4 & 6.5 & 70 \\
\hline \multirow[t]{3}{*}{10} & $\mathrm{H}$ & N.A. & - & - & - & - & - & - & - & - & - \\
\hline & $\mathrm{H}$ & 0.1259 & 6.6 & 24 & ND & 26.6 & 4.5 & 28.4 & 5.5 & 10.7 & 72 \\
\hline & $\mathrm{L}$ & 0.1429 & 6.5 & 15.6 & ND & 22.6 & 5.1 & 28.7 & 5.4 & 8.4 & 65 \\
\hline \multirow[t]{3}{*}{11} & $\mathrm{H}$ & 0.0849 & 6.1 & 9 & 2.0 & 20 & 5.6 & 25 & 1.9 & N.A. & 55 \\
\hline & $\mathrm{H}$ & 0.1521 & 6.5 & 15 & ND & 21.9 & 5.4 & 28.3 & 5.6 & 10.6 & 67 \\
\hline & $\mathrm{L}$ & 0.1892 & 6.5 & 17.1 & ND & 23.3 & 5.0 & 27.9 & 5.9 & 8.2 & 61 \\
\hline \multirow[t]{3}{*}{12} & $\mathrm{H}$ & 0.1045 & 6.5 & 12 & ND & 24 & 4.4 & 27.8 & 1.4 & N.A. & 55 \\
\hline & $\mathrm{H}$ & N.A. & - & - & - & - & - & - & - & - & - \\
\hline & $\mathrm{L}$ & 0.267 & 6.5 & 17 & ND & 25.9 & 4.6 & 27.5 & 2.4 & 10.6 & 66 \\
\hline DEP & & $2.0^{\mathrm{a}}$ & 6.0 & N.A. & $2.75^{\mathrm{b}}$ & N.A. & 5.0 & $32.4^{\mathrm{C}}$ & $41.3^{\mathrm{d}}$ & Mean $=7.6$ & $113.9^{\mathrm{e}}$ \\
\hline EPA & & $1.4-4.8^{\mathrm{a}}$ & 6.5 & N.A. & $2.64^{\mathrm{b}}$ & N.A. & 5.0 & - & - & - & - \\
\hline \multicolumn{12}{|c|}{$\begin{array}{l}{ }^{\mathrm{a}} \text { Augspurger et al. (2 } \\
\text { ity standard. For the } \\
\text { nia }\left(\mathrm{NH}_{3} \text { and } \mathrm{NH}_{4}+\right)\end{array}$} \\
\hline \multicolumn{12}{|c|}{$\begin{array}{l}{ }^{\mathrm{b}} \mathrm{US} \text { Environmental P } \\
\text { (F.A.C. [Florida Adn } \\
23.9 \mathrm{mg} \mathrm{l}^{-1} \mathrm{CaCO}_{3}\end{array}$} \\
\hline \multicolumn{12}{|c|}{$\begin{array}{l}{ }^{\mathrm{c}} \text { Overall summer season mean of } 27.4^{\circ} \mathrm{C} \text { used to determine Florida thermal water quality standards violations (F.A.C. } 2004 \text {, in ex- } \\
\text { cess of mean background temperature plus } 5^{\circ} \mathrm{C} \text {, intended for thermal point source discharges) }\end{array}$} \\
\hline \multicolumn{12}{|c|}{$\begin{array}{l}\text { dOverall summer season mean of } 12.3 \text { NTUs used to determine Florida water quality standards violations (F.A.C. } 2004, \geq 29 \text { above } \\
\text { natural background conditions }\end{array}$} \\
\hline \multicolumn{12}{|c|}{$\begin{array}{l}\text { eOverall summer season mean of } 75.9 \text { used to determine Florida water quality standards violations (F.A.C. 2004, in excess of } \\
\text { mean background plus } 50 \% \text { or } 1275 \mu \mathrm{S} \mathrm{cm}^{-3} \text {, whichever is greater }\end{array}$} \\
\hline
\end{tabular}

copper, respectively), it was particularly noteworthy

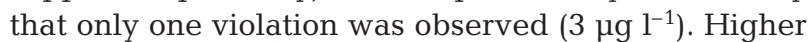
water hardness, a measure of the concentration of divalent $(2+)$ cations, acts to naturally chelate or bind ionic metals, reducing their toxicity. Higher water hardness values would have resulted in the calculation 
of a higher copper (metals) state standard or USEPA criterion that would have estimated the same concentration of biologically available copper.

Dissolved oxygen concentrations were consistently below desired levels $\left(\mathrm{n}=12\right.$ readings $<5 \mathrm{mg} \mathrm{l}^{-1}$ ), state standard (5 $\left.\mathrm{mg} \mathrm{l}^{-1}\right)$ and the USEPA criterion (5 $\mathrm{mg} \mathrm{l}^{-1}$ ) in the reach of the Ochlockonee River below Lake Talquin ( $\mathrm{n}=12$ readings from 2.3 to $4.6 \mathrm{mg} \mathrm{l}^{-1}$ ), as well as at several upstream sites $(n=3$ readings from 4.5 to $4.9 \mathrm{mg} \mathrm{l}^{-1}$ ). These measures were taken during the summer months with assumed annually high water temperatures $\left(25.6\right.$ to $\left.29.2^{\circ} \mathrm{C}\right)$. However, despite warmer temperatures, less than half of the oxygen that could be dissolved in waters from the site just below the dam was found in those samples. Because the estimation of percent oxygen saturation takes temperature into account, it is particularly useful as an indicator of high oxygen demand from chemical or biological sources. However, the low percent saturation with oxygen may have simply resulted from limited oxygen introduction through mixing or turbulence.

Low oxygen levels have been implicated as stressors to invertebrate and fish species (Sprague 1963, Dahlberg et al. 1968, Nebeker 1972, USEPA 1986, Nebeker et al. 1992 ). Additionally, dams alone have been cited as the cause of extirpation for 30 to $60 \%$ of the native mussel species in select US rivers because they can cause reduced dissolve oxygen and create other challenges via their alteration of flow regimes (Williams et al. 1992, Layzer et al. 1993). We found that turbidity exceeded the state water quality standard (41 NTU) on one occasion (49.3 NTU) in the Little River tributary just above Lake Talquin, but did not appear to result from algal production $\left(6.1 \mu \mathrm{g} \mathrm{l^{-1 }}\right.$ chlorophyll a). However, the river segments downstream of Lake Talquin did have higher chlorophyll a concentrations (6.5 to $11.0 \mu \mathrm{g} \mathrm{l}^{-1}$ chlorophyll a) than those sites above the lake (0.6 to $7.6 \mu \mathrm{g} \mathrm{l}^{-1}$ chlorophyll a). Specific conductance was low in the system and was not expected to differ from historical.

\section{Sediment quality}

\section{Sediment toxicity tests}

Toxicity test results are provided for reference in (Table 2). Survival of Hyalella azteca exposed to sediment porewater from 3 sites was significantly lower compared to the control. H. azteca survival in exposures to the solid-phase sediments did not differ from the control at any of the sites. Length of $H$. azteca was significantly less than the control-sediment exposures in sediments from 10 sites. The large number of sites showing a significant difference in length may be partially explained by the comparatively large size of the animals from control sediment. If length from exposures to sediment from Stn 8 (greatest length of $H$. azteca from the test sediments) were used for comparison as a field reference site, no significant differences in length would be detected. Because of the large size

Table 2. Percent survival and growth (expressed as total length, $\mathrm{mm}$ ) of Hyalella azteca exposed to pore water (n $=50$ site ${ }^{-1}$ ) and solid-phase sediments $\left(\mathrm{n}=50\right.$ site $\left.^{-1}\right)$ collected from the Ochlockonee River, Florida, in August 2004, and EC50s at 5 and 15 min exposures of sediment extract to Vibrio fischeri (Microtox, $\mathrm{n}=3$ treatment $^{-1}$ ). Values in parentheses are standard deviations, and values with an asterisk indicate a significant difference $(\mathrm{p}<0.05)$ to the Control. Comparisons were made to laboratory-control sediment (Control, commercial sand that was washed and held in test water for $2 \mathrm{wk}$ prior to use), a laboratory reference sample (Reference, sediments collected from Lake Buford in northern Georgia for which the laboratory has extensive data), and reconstituted hard water (Recon) exposures

\begin{tabular}{|lccccc|}
\hline & \multirow{2}{*}{$\begin{array}{c}\text { Pore water } \\
\text { Percent survival }\end{array}$} & \multicolumn{2}{c}{ Solid-phase sediment } & & \multicolumn{2}{c|}{ Microtox } \\
\cline { 3 - 5 } & Percent survival & Length (mm) & & EC50-5 min (mg) & EC50-15 min (mg) \\
\hline 0104 & $42(26)^{*}$ & $92(8)$ & $4.01(0.3)^{*}$ & $93(11)^{*}$ & $76(8)^{*}$ \\
0204 & $86(11)$ & $92(4)$ & $4.03(0.4)^{*}$ & $221(11)$ & $278(17)$ \\
0304 & $100(0)$ & $96(5)$ & $4.46(0.4)$ & $178(38)$ & $147(27)$ \\
0404 & $94(10)$ & $98(4)$ & $4.57(0.5)$ & $282(11)$ & $295(2)$ \\
0504 & $50(16)^{*}$ & $94(9)$ & $4.21(0.3)^{*}$ & $99(9)^{*}$ & $135(11)$ \\
0604 & $88(13)$ & $100(0)$ & $4.11(0.2)^{*}$ & $186(9)$ & $182(8)$ \\
0704 & $82(13)$ & $90(12)$ & $4.29(0.3)^{*}$ & $134(4)$ & $137(5)$ \\
0804 & $100(0)$ & $98(4)$ & $4.39(0.4)^{*}$ & $207(25)$ & $182(21)$ \\
0904 & $100(0)$ & $96(5)$ & $4.31(0.5)^{*}$ & $120(7)$ & $106(3)$ \\
1004 & $92(18)$ & $92(8)$ & $4.31(0.3)^{*}$ & $277(6)$ & $261(12)$ \\
1104 & $76(9)^{*}$ & $96(9)$ & $4.26(0.3)^{*}$ & $268(52)$ & $306(64)$ \\
1204 & $80(12)$ & $92(8)$ & $3.41(0.3)^{*}$ & $171(17)$ & $158(19)$ \\
Reference & $90(10)$ & $96(5)$ & $4.61(0.4)$ & $115(3)$ & $156(29)$ \\
Control & $98(4)$ & - & - & - & $113(4)$ \\
Recon & $90(10)$ & & & - \\
\hline
\end{tabular}


of animals from the control sediments, the significance of the statistical differences with the control may be questioned.

Microtox bioassays showed significant EC50 differences between the laboratory control and Stns 1 and 5 for the 5 min exposures. The 15 min exposures showed only a significant difference at Stn 1.

Based on the data from the 3 sets of toxicity tests, sediments at Stns $1 \& 5$ (and possibly 11) may be somewhat impaired in terms of supporting aquatic life in general. Stn 1 is at the lower end of the Little River north of Lake Talquin and southeast of Quincy, Florida; Stn 5 is in southern Georgia, southeast of Cairo. Sediment quality from the other sites does not appear to limit aquatic organisms. However, toxicity tests with appropriate mussel surrogates will be needed to verify that freshwater mussels are not limited by sediment toxicity at these sites.

\section{Sediment analyses}

Porewater chemistry from the sediments (Table 3) was within natural variability. Although ammonia concentrations (both total and un-ionized) were elevated at several locations (Stns 1, 2, 5, 8, 9, 10 and 11), there was no direct relationship to survival of the test species (no dose-response relationship). However, the concentration at Stn 1 could have influenced survival at that site. Un-ionized ammonia exceeded the $0.02 \mathrm{mg} \mathrm{l}^{-1}$ estimated safe level for freshwater mussels at 10 of the 12 sites (Augspurger et al. 2003), but survival of Hyalella azteca in porewater did not reflect these elevated levels. H. azteca are reported to be far less sensitive to un-ionized ammonia than many freshwater mussel species (0.4 mg NH $\mathrm{l}^{-1}$, DMMP 2001; USEPA \& USACE 1993), warranting further investigation with mussel-specific assays. Other porewater chemical characteristics were within acceptable ranges for $H$. azteca.

Chemistry of overlying water from the solid-phase exposure tests was also within expected ranges and changed little during the toxicity testing. Ammonia was slightly elevated at a few sites (the same sites that had elevated concentrations in the porewater tests) at the start of the test, but concentrations were well below levels of concern. Unfortunately, the overlying water samples were inadvertently discarded at the end of the test before ammonia could be measured. Ammonia concentrations in the overlying water from the solid-phase exposures generally decline during the course of the test due to the daily replacement of the water. Consequently, ammonia concentrations in the overlying water at the end of the solid-phase exposures would be expected to be less (probably nondetectable) than those measured at the start of the test.

The physical characteristics of the sediments varied little from site to site (Table 4). Organic matter was generally low (0.5 to $7.2 \%$ of sediment composition) and the sediments consisted primarily of sand (89.5 to $97.5 \%$ ). Acid volatile sulfides (AVS) were low (from not detected to $0.14 \mu_{\mathrm{mol} \mathrm{g}}{ }^{-1}$ ), as were concentrations of the simultaneously extracted metals (SEM, 0.03 to $\left.0.5 \mu \mathrm{mol} \mathrm{g}^{-1}\right)$. These small concentrations were most likely responsible for the inordinately high ratios shown for the SEM/AVS (0.00 to $16.64 \mu \mathrm{mol} \mathrm{g}{ }^{-1}$ ). Ratios of SEM/AVS exceeding 1 are generally considered predictive of metal toxicity (Di Toro et al. 1992). In this

Table 3. Chemistry of porewater extracted from sediment collected from the Ochlockonee River, August 2004. bdl: not detected within the limits of the methods used; Tot amm: total ammonia

\begin{tabular}{|c|c|c|c|c|c|c|c|c|c|c|c|c|c|c|}
\hline \multirow[t]{2}{*}{ Station } & \multirow{2}{*}{$\begin{array}{l}\text { Temp } \\
\left({ }^{\circ} \mathrm{C}\right)\end{array}$} & \multirow{2}{*}{$\begin{array}{c}\mathrm{DO} \\
\left(\mu g \mathrm{l}^{-1}\right)\end{array}$} & \multirow[t]{2}{*}{$\mathrm{pH}$} & \multirow{2}{*}{$\begin{array}{c}\text { Cond } \\
\left(\mu \mathrm{S} \mathrm{cm}^{-1}\right.\end{array}$} & \multirow{2}{*}{$\begin{array}{c}\text { Alk } \\
\text { (1) }\left(\mathrm{mg} \mathrm{l}^{-1}\right)\end{array}$} & \multirow{2}{*}{$\begin{array}{l}\text { Hard } \\
\left(\mathrm{mg} \mathrm{l}^{-1}\right)\end{array}$} & \multirow{2}{*}{$\begin{array}{c}\text { Tot amm } \\
\left(\mathrm{mg} \mathrm{l}^{-1}\right)\end{array}$} & \multirow{2}{*}{$\begin{array}{l}\text { UnNH3 } \\
\left(\mathrm{mg} \mathrm{l}^{-1}\right)\end{array}$} & \multicolumn{3}{|c|}{ Anions $\left(\mathrm{mg} \mathrm{l}^{-1}\right)$} & \multicolumn{3}{|c|}{ Dissolved carbon $\left(\mathrm{mg} \mathrm{l}^{-1}\right)$} \\
\hline & & & & & & & & & Chloride & Nitrate & Sulfate & Inorganic & Organic & Total \\
\hline 0104 & 23 & 6.5 & 7.61 & 632 & 308 & 204 & 16.0 & 0.31 & 8.22 & 1.16 & ND & 83.08 & 11.14 & 94.22 \\
\hline 0204 & 23 & 6.8 & 8.30 & 515 & 260 & 156 & 6.0 & 0.54 & 6.98 & bdl & 0.34 & 69.01 & 4.64 & 73.65 \\
\hline 0304 & 23 & 6.6 & 8.00 & 165 & 70 & 24 & 1.4 & 0.06 & 10.52 & bdl & 0.42 & 18.26 & 15.61 & 33.87 \\
\hline 0404 & 23 & 7.5 & 7.77 & 141 & 72 & 18 & 1.7 & 0.05 & 8.37 & 1.52 & 6.99 & 9.79 & 8.03 & 17.82 \\
\hline 0504 & 23 & 5.6 & 6.98 & 163 & 78 & 19 & 7.6 & 0.04 & 10.29 & 0.33 & 1.06 & 14.97 & 15.4 & 30.37 \\
\hline 0604 & 23 & 7.5 & 7.49 & 256 & 130 & 85 & 1.9 & 0.03 & 8.47 & bdl & 0.84 & 31.00 & 8.52 & 39.52 \\
\hline 0704 & 23 & 8.1 & 7.25 & 294 & 62 & 38 & 0.7 & bdl & 9.93 & 10.81 & 18.77 & 14.55 & 7.59 & 21.14 \\
\hline 0804 & 23 & 7.1 & 7.71 & 265 & 108 & 61 & 6.6 & 0.16 & 8.90 & bdl & 3.65 & 29.88 & 8.87 & 38.75 \\
\hline 0904 & 23 & 7.5 & 8.02 & 300 & 138 & 63 & 8.4 & 0.39 & 11.40 & bdl & 0.97 & 36.11 & 9.92 & 46.03 \\
\hline 1004 & 23 & 5.8 & 7.67 & 279 & 130 & 56 & 14.8 & 0.36 & 8.32 & bdl & 0.36 & 30.13 & 17.94 & 48.07 \\
\hline 1104 & 23 & 7.3 & 8.14 & 385 & 194 & 121 & 6.1 & 0.36 & 6.06 & bdl & 0.35 & 52.25 & 4.47 & 56.72 \\
\hline 1204 & 23 & 7.7 & 8.05 & 338 & 196 & 101 & 1.5 & 0.07 & 11.05 & bdl & 2.29 & 38.41 & 5.58 & 43.99 \\
\hline Reference & 23 & 8.4 & 8.13 & 225 & 110 & 49 & bdl & bdl & 2.23 & 0.25 & 0.57 & 33.86 & 9.52 & 43.38 \\
\hline Control & 23 & 8.9 & 8.13 & 413 & 84 & 86 & bdl & bdl & 39.02 & 2.65 & 61.55 & 20.50 & 2.27 & 22.77 \\
\hline Recon & 23 & 8.2 & 8.14 & 404 & 78 & 85 & bdl & bdl & 38.95 & 1.96 & 65.97 & 17.18 & 0.34 & 17.52 \\
\hline
\end{tabular}


Table 4. Physical characteristics of the sediments and acid volatile sulfides (AVS), simultaneously extracted metals (SEM) and the SEM/AVS ratio for sediments collected from the Ochlockonee River, Florida, in August 2004. bdl: not detected within the imits of the methods used

\begin{tabular}{|c|c|c|c|c|c|c|c|c|c|}
\hline \multirow[t]{2}{*}{ Station } & \multicolumn{6}{|c|}{ Sediment characteristics (\%) } & \multicolumn{3}{|c|}{ Acid volatile sulfides $\left(\mu \mathrm{mol} \mathrm{g}{ }^{-1}\right)$} \\
\hline & Moisture & Total organic & Coarse organic & Sand & Silt & Clay & AVS & SEM & SEM/AVS \\
\hline 0104 & 31.6 & 1.8 & 0.7 & 91.2 & 5.1 & 3.7 & 0.08 & 0.17 & 2.09 \\
\hline 0204 & 23.8 & 0.8 & 0.3 & 92.1 & 4.9 & 2.9 & 0.05 & 0.09 & 1.95 \\
\hline 0304 & 27.1 & 2.4 & 1.2 & 89.5 & 5.3 & 5.2 & 0.06 & 0.33 & 5.86 \\
\hline 0404 & 19.1 & 0.1 & 0.0 & 98.8 & 0.9 & 0.3 & bdl & 0.03 & 0.00 \\
\hline 0504 & 31.6 & 2.7 & 1.8 & 94.4 & 4.0 & 1.6 & 0.03 & 0.09 & 2.62 \\
\hline 0604 & 28.9 & 1.3 & 0.8 & 89.5 & 5.9 & 4.6 & 0.14 & 0.11 & 0.76 \\
\hline 0704 & 20.4 & 0.5 & 0.2 & 94.9 & 2.2 & 2.9 & 0.00 & 0.07 & 16.64 \\
\hline 0804 & 25.7 & 0.8 & 0.5 & 97.5 & 1.8 & 0.7 & 0.02 & 0.05 & 2.77 \\
\hline 0904 & 24.9 & 1.8 & 0.7 & 91.8 & 4.8 & 3.4 & 0.02 & 0.08 & 5.46 \\
\hline 1004 & 32.1 & 2.1 & 1.5 & 93.6 & 4.1 & 2.3 & 0.06 & 0.10 & 1.60 \\
\hline 1104 & 40.2 & 7.2 & 4.7 & 93.7 & 3.2 & 3.1 & 0.07 & 0.25 & 3.61 \\
\hline 1204 & 21.4 & 0.5 & 1.0 & 91.5 & 2.7 & 5.8 & 0.00 & 0.07 & 14.21 \\
\hline Reference & 49.9 & 7.8 & 5.7 & 76.0 & 19.1 & 4.9 & 0.05 & 0.50 & 9.26 \\
\hline Control & 28.7 & 0.1 & 0.1 & 98.3 & 1.6 & 0.1 & 0.00 & 0.03 & 96.30 \\
\hline
\end{tabular}

case, however, the metal concentrations would not be expected to exceed toxic thresholds. The metals were more likely to be bound to dissolved organic matter in the porewater and be unavailable.

Concentrations of trace elements in porewater (Table 5) were generally below levels that are expected to adversely affect aquatic species and substantially lower than water quality criteria (US EPA 2002). The only exception was lead, which had concentrations at Stns 2, 3, 4 and 7 that exceeded the 2.5 $\mu \mathrm{g}^{-1}$ continuous criteria concentration (CCC). Concentrations of $\mathrm{Pb}$ exceeded aquatic effects levels of 1 to $5 \mathrm{\mu g} \mathrm{l}^{-1}$ (Eisler 1988) at 7 of the 12 test sites, but
Hyalella azteca survival in porewater did not correspond to these levels, and lead toxicity to freshwater mussels is not well known. In addition, the manganese concentration in porewater from Stn 1 was within the toxic range or 3 to $13 \mathrm{mg} \mathrm{l}^{-1}$ for $H$. azteca, depending on water hardness (Lasier et al. 2000), and may have contributed to the reduced survival for this site. Similarly, concentrations of trace elements in the solidphase sediments were generally low and considerably less than sediment quality guidelines (MacDonald et al. 2000); except for lead at Stn 7 (site just below the Lake Talquin dam), exceeding the Threshold Effects Level (TEL) of $35.8 \mathrm{mg} \mathrm{kg}^{-1}$.

Table 5. Concentrations of trace elements in porewaters from sediments collected from the Ochlockonee River in August 2004. bdl: not detected within the limits of the methods used

\begin{tabular}{|c|c|c|c|c|c|c|c|c|c|c|c|c|c|c|c|c|}
\hline Station & $\begin{array}{c}\mathrm{Ag} \\
\left(\mu \mathrm{g} \mathrm{l}^{-1}\right)\end{array}$ & $\begin{array}{c}\text { As } \\
\left(\mu \mathrm{g} \mathrm{l}^{-1}\right)\end{array}$ & $\begin{array}{c}\mathrm{Ca} \\
\left(\mathrm{mg} \mathrm{l}^{-1}\right)\end{array}$ & $\begin{array}{c}\mathrm{Cd} \\
\left(\mu \mathrm{g} \mathrm{l}^{-1}\right)\end{array}$ & $\begin{array}{c}\mathrm{Cu} \\
\left(\mu \mathrm{g} \mathrm{l}^{-1}\right)\end{array}$ & $\begin{array}{c}\mathrm{Cr} \\
\left(\mu \mathrm{g} \mathrm{l}^{-1}\right)\end{array}$ & $\begin{array}{c}\mathrm{Fe} \\
\left(\mathrm{mg} \mathrm{l}^{-1}\right.\end{array}$ & 1) $\frac{\mathrm{K}}{\left(\mathrm{mg} \mathrm{l}^{-1}\right)}$ & $\begin{array}{c}\mathrm{Hg} \\
\left(\mu \mathrm{g} \mathrm{l}^{-1}\right)\end{array}$ & $\underset{\left(\mathrm{mg} \mathrm{l}^{-1}\right)}{\mathrm{Mg}}$ & $\begin{array}{c}\mathrm{Mn} \\
\left(\mu \mathrm{g} \mathrm{l}^{-1}\right)\end{array}$ & $\begin{array}{c}\mathrm{Na} \\
\left(\mathrm{mg} \mathrm{l}^{-1}\right)\end{array}$ & $\begin{array}{c}\mathrm{Ni} \\
\left(\mu \mathrm{g} \mathrm{l}^{-1}\right)\end{array}$ & $\begin{array}{c}\mathrm{Pb} \\
\left(\mu \mathrm{g} \mathrm{l}^{-1}\right)\end{array}$ & $\begin{array}{c}\mathrm{Se} \\
\left(\mu \mathrm{g} \mathrm{l}^{-1}\right)\end{array}$ & $\begin{array}{c}\mathrm{Zn} \\
\left(\mu \mathrm{g} \mathrm{l}^{-1}\right)\end{array}$ \\
\hline 0104 & 0.74 & 2.64 & 60.37 & 0.06 & 1.42 & bdl & 3.07 & 3.54 & bdl & 13.09 & 8.45 & 19.34 & 1.92 & 0.38 & 0.30 & 23.66 \\
\hline 0304 & 0.13 & 2.16 & 6.53 & bdl & 2.96 & 0.91 & 0.42 & 2.57 & bdl & 1.98 & 0.35 & 19.04 & 1.24 & 6.51 & 0.89 & 49.24 \\
\hline 0404 & 1.06 & 0.70 & 4.29 & 0.01 & 2.30 & 0.61 & 0.48 & 2.79 & bdl & 1.70 & 0.01 & 15.62 & 8.93 & 13.90 & 0.74 & 85.84 \\
\hline 0504 & 2.76 & 2.25 & 5.41 & 0.02 & 1.29 & 0.17 & 0.22 & 2.75 & bdl & 1.40 & 0.26 & 13.68 & 1.15 & 1.21 & 1.12 & 22.69 \\
\hline 0804 & 4.80 & 4.26 & 16.89 & bdl & 0.81 & bdl & 0.11 & 2.42 & bdl & 4.47 & 1.35 & 14.03 & 0.26 & 0.37 & 0.16 & 14.44 \\
\hline 0904 & 0.80 & 2.28 & 19.05 & bdl & 0.60 & bdl & 0.10 & 2.21 & bdl & 3.82 & 0.56 & 22.19 & 0.15 & 0.51 & 0.82 & 19.72 \\
\hline 1004 & 1.10 & 3.74 & 17.57 & bdl & 0.66 & 0.28 & 0.19 & 2.32 & bdl & 2.89 & 1.77 & 15.51 & 0.71 & 0.36 & 0.52 & 28.94 \\
\hline 1104 & 1.66 & 1.73 & 35.74 & 0.00 & 0.30 & bdl & 0.07 & 0.93 & bdl & 7.74 & 0.32 & 14.89 & 1.13 & 2.34 & 1.02 & 39.64 \\
\hline 1204 & 9.70 & 5.37 & 27.65 & 0.08 & 0.71 & 0.94 & 0.14 & 2.14 & bdl & 7.77 & 0.14 & 21.04 & 0.99 & 1.19 & 0.51 & 8.26 \\
\hline Reference & 1.07 & 0.93 & 13.68 & 0.03 & 1.94 & 0.31 & 5.25 & 1.85 & bdl & 3.31 & 3.56 & 14.72 & 1.72 & 0.22 & 3.72 & 69.72 \\
\hline
\end{tabular}


Concentrations of lead also were somewhat elevated at Stns 3 (upstream of the dam and south of Cairo, Georgia) and 11 (on the lower river near the bay). Although concentrations of trace metals in porewaters and sediments from the Ochlockonee River appear to be below effects levels for aquatic life, concentrations that could have long-term chronic effects are not known.

\section{Evaluation of potential risk and land use analysis}

Sites with a risk estimation score of 5 or greater corresponded well with areas where mussel populations have declined (Fig. 4; below the dam, Little River, and $\sim 3$ miles SSE of Cairo, Georgia), and as such were considered to be of diminished value to freshwater mussels (Table 6). Conversely, sites with cumulative scores below 4 were found in areas that were apparently less impacted by anthropogenic changes. However, 2 sites where protected mussels have not recently been found had cumulative risk scores of 2 (second site below Lake Talquin) or 1 (uppermost northern sampling point NW of Thomasville, Georgia), respectively. This may have resulted from a number of factors including, but not

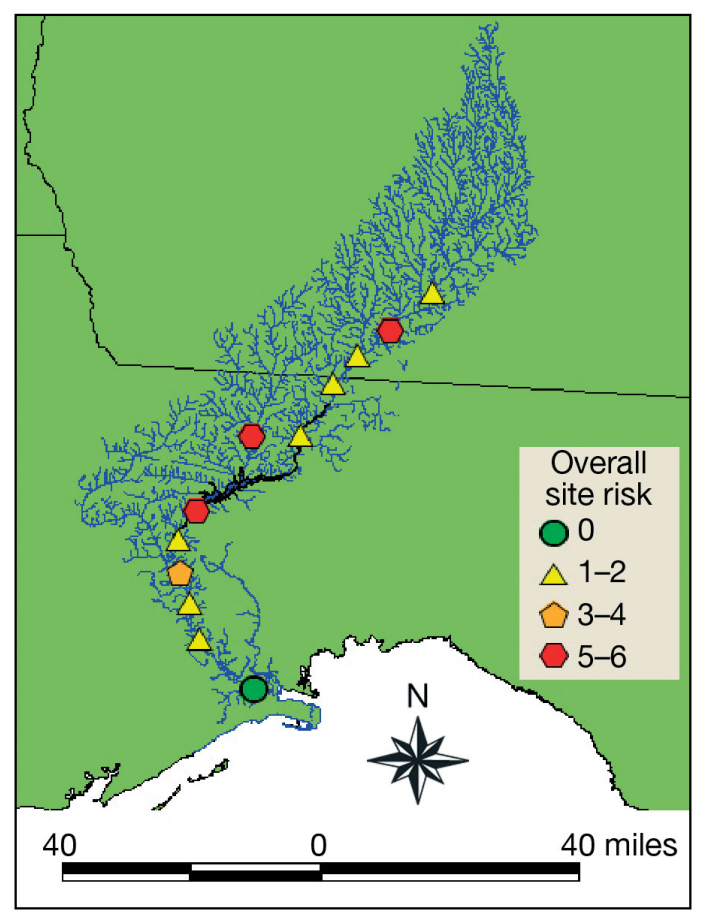

Fig. 4. Cumulative risk score estimated for riverine communities in the Ochlockonee River, Florida based on sampling conducted in the summer of 2004. Water quality standards violations, toxicity test differences from the control, or exceeded sediment analyte guidelines each represented one risk point assessed to be summed for each incidence of each parameter by site restricted to: (1) the factors that limit mussels were missed by the survey and therefore risk was underestimated; (2) factors contributing to the decline of the mussels were not chemical in nature at the site; (3) the factors at nearby sites limited the success of the mussels; (4) the mussels' absence was related to an apparent decline that may more accurately be described as a decline in detection probability (Bailey et al. 2004); or (5) differences in sampling effort over time.

Failure to meet water quality standards has been reported for the Ochlockonee River system (FDEP 2001, GDNR 2002). In Georgia, the upper Ochlockonee River basin has the designation of 'fishing' waters meaning that it suitable for fishing and swimming, but not consumption. According to the State of Georgia (GDNR 2002), this area of the river has frequently been noted for violations of the dissolved oxygen and fecal coliform bacteria standards, but also for fish consumption advisories. In nearly every instance the cause of the impairment has been attributed to non-point-source pollution (GDNR 2002). The State of Georgia is addressing these issues through the implementation of their watershed protection strategy (GDNR 2002). Parameters leading to impairment in Georgia have also prevented the Ochlockonee River in Florida from meeting its 'fishable-swimmable' (suitable for fishing and swimming, but not consumption) designation at a number of locations (FDEP 2001). Parameters necessitating listing on the impaired water list included low dissolved oxygen, eutrophication, elevated turbidity, high total suspended solids (TSS), high bacterial loads, fish mercury content, biological integrity (macroinvertebrates) and iron. Like the sub-watersheds (drainage partitions within the watershed) in Georgia, the water quality impairments have been reported to stem largely from nonpoint sources (FDEP 2001).

Although numerous instances of water quality violation have been reported by the respective state agencies, low dissolved oxygen may be the primary parameter that impacts aquatic life in the Ochlockonee River. In the case of freshwater mussels, low dissolved oxygen may interfere with respiration or the presence of needed fish hosts for reproduction (Sprague1963, Dahlberg et al. 1968, Nebeker 1972, USEPA 1986, Nebeker et al. 1992).

In addition to the non-point contribution to the quality of the system's water and sediment, point source discharges permitted by the respective states via the National Pollutant Discharge Elimination System (NPDES) exist in the watershed. Two reaches of the Ochlockonee River, where high risk was estimated for aquatic life, possessed a number of point source discharges in their sub-drainages. The permitted discharges included domestic wastewater treatment plants, petroleum wholesalers, plant nurseries, mining 
Table 6. Individual parameters providing the cumulative potential risk score estimated for riverine communities in the Ochlockonee River, Florida, based on sampling conducted in the summer of 2004. Water quality standards violations, toxicity test differences from the control or exceeded sediment analyte guidelines are listed with respective parameter for each incidence. Each reported incidence represented one risk point assessed. Sites with ${ }^{\prime * \prime}$ had no federally listed threatened or endangered freshwater mussel species during 2002-2004 surveys

\begin{tabular}{|c|c|c|c|}
\hline Site & $\begin{array}{l}\text { Water quality } \\
\text { violation }\end{array}$ & Toxicity test & Guidance exceeded \\
\hline $\begin{array}{l}1^{*} \\
6 \text { points }\end{array}$ & & $\begin{array}{l}H . \text { azteca porewater } \\
5 \text { min } V . \text { fischeri } \\
15 \text { min } V . \text { fischeri }\end{array}$ & $\begin{array}{l}\text { Total ammonia } \\
\text { Unionized ammonia } \\
\text { Manganese }\end{array}$ \\
\hline $\begin{array}{l}5^{*} \\
5 \text { points }\end{array}$ & $\begin{array}{l}\text { Dissolved oxygen } \\
\text { Free copper }\end{array}$ & $\begin{array}{l}\text { H. azteca porewater } \\
5 \text { min } V . \text { fischeri }\end{array}$ & Total ammonia \\
\hline $\begin{array}{l}7^{*} \\
5 \text { points }\end{array}$ & $\begin{array}{l}\text { Dissolved oxygen } \\
\text { Dissolved oxygen } \\
\text { Dissolved oxygen }\end{array}$ & & $\begin{array}{l}\text { Lead (porewater) } \\
\text { Lead (whole sediment) }\end{array}$ \\
\hline $\begin{array}{l}9 \\
3 \text { points }\end{array}$ & $\begin{array}{l}\text { Dissolved oxygen } \\
\text { Dissolved oxygen }\end{array}$ & & Total ammonia \\
\hline $\begin{array}{l}2^{*} \\
2 \text { points }\end{array}$ & & & $\begin{array}{l}\text { Unionized ammonia } \\
\text { Lead (porewater) }\end{array}$ \\
\hline $\begin{array}{l}4 \\
2 \text { points }\end{array}$ & Dissolved oxygen & & Lead (porewater) \\
\hline $\begin{array}{l}8^{*} \\
2 \text { points }\end{array}$ & Dissolved oxygen & & Total ammonia \\
\hline $\begin{array}{l}10 \\
2 \text { points }\end{array}$ & Dissolved oxygen & & Total ammonia \\
\hline $\begin{array}{l}11 \\
2 \text { points }\end{array}$ & & H. azteca porewater & Total ammonia \\
\hline $\begin{array}{l}6^{*} \\
1 \text { point }\end{array}$ & Turbidity & & \\
\hline $\begin{array}{l}12 \\
0 \text { points }\end{array}$ & None & & \\
\hline
\end{tabular}

and manufacturing, a meat processing plant, mining operation to produce absorbents, and a state hospital. However, the discharges were all upstream of Site 6 (the uppermost site sampled) but the overall risk score for that site was considerably lower than Site 5 further downstream.

The third high risk site was located immediately below the dam on Lake Talquin. Lake Talquin is a man-made reservoir formed in 1927 when the Jackson Bluff Dam was constructed on the Ochlockonee River to produce hydroelectric power. Water from Lake Talquin is released through the dam via an underwater intake and surface discharge overflow from reservoir level gates. The design of the discharge may be related to the low dissolved oxygen levels recorded at the site. The State of Florida refers to Lake Talquin as more of a recreational feature than source of electric power for the City of Tallahassee (FDEP 2001).

General land use characterizations provided by the respective state water management authorities have shown important differences between sub-drainages
(FDEP 2001, GDNR 2002). According to these state agencies, the upper Ochlockonee River in Georgia, for example, possesses considerably more agriculture and rangeland (36 and $13 \%$, respectively) than the upper river in Florida (9 and 3\%, respectively) or lower river in Florida (0.4 and $2 \%$, respectively). Agriculture and rangeland have often been associated with loadings that contribute to violations of dissolved oxygen and fecal coliform bacteria standards (FDEP 2001, GDNR 2002). The upper Ochlockonee River in Georgia also contains a large percent coverage of upland forest (41\%), as does the Florida upper river (68\%) and the lower river in Florida below Lake Talquin (51\%). The upper river in Florida has more urban development $(8 \%)$, compared to either Georgia $(2 \%)$ or the lower river in Florida $(1 \%)$. And the lower river has far more wetland coverage $(43 \%)$ than either of the other 2 sub-drainages (Georgia 8\% and Florida 8\%; FDEP 2001, GDNR 2002). In fact, upland forest, wetland and open water categories combined constitute over $95 \%$ of the sub-drainage area of the lower river in Florida (FDEP 2001).

Potential sources of nonpoint contributions in the sub-drainages can be identified based on land use characteristics provided by the states. The estimated important non-point contributors for Georgia's upper river area would include primarily agriculture and rangeland, but the importance of barren lands has not been overlooked by the respective state agencies (FDEP 2001, GDNR 2002). The upper Ochlockonee River in Florida possesses the highest urban development, as well as considerable amounts of agriculture and rangeland. The most important candidate for the lower river in Florida may have been rangeland. However, contributions of extensive upland forest management should not be omitted.

The above summary was based on land-use analyses on the landscape-level in which the Ochlockonee River watershed was viewed as only 3 sub-watersheds (FDEP 2001, GDNR 2002). The understanding of water and sediment quality limitations could be refined by improving on the scale of the land use divisions (large scale analyses, smaller size sub-watershed land use definitions). The estimated high risk areas for aquatic 
communities should be subjected to such analyses. Large-scale analyses should include important spatial issues such as distance of a particular land-use within a sub-drainage from the concern point, cumulative contributions between specific sub-watersheds, and potentially historical land-uses from which recovery may be taking place (Paul Lang, USFWS, pers. comm.).

\section{CONCLUSIONS}

Estimated risk to aquatic species was based on protective USEPA criteria and state water quality standards. Most often risk may have been related to low dissolved oxygen, and to a lesser extent turbidity and free copper concentrations in some instances. As a result, the coincidence of mussel absence (based on reference data) and water quality violations most often occurred with violations of the dissolved oxygen water quality criterion. Proximate areas of concern have been identified for water quality impairment, including the area immediately below Lake Talquin. However, a more systematic survey of the sub-watersheds where there is a risk from water quality parameters, such as low dissolved oxygen, is needed. Tributaries to some of the observed high risk may also be limiting to riverine community success to a degree that needs to be defined. Additionally, the extent of the reach that was identified as limiting (Sprague 1963, Dahlberg et al. 1968, Nebeker 1972, USEPA 1986, Nebeker et al. 1992) needs to be revealed through a more systematic approach to better delineate areas for improvement versus areas where recovery efforts would be more suitably employed.

In general, the sediment quality from the Ochlockonee River appeared to be fairly good, with the exception of Stns 1 and 5 (and maybe 11). Specific factors responsible for the reduced Hyalella azteca survival and low $V$. fischeri EC50 values shown for these sites are not known. Ammonia and manganese concentrations may be important at Stn 1. Ammonia and lead at various sites in this river were elevated, but there was no clear linear relationship between dose and effect (test endpoints). Sites with the highest concentrations did not show a corresponding toxic response. The concentrations of trace metals shown in the porewater and in the solid-phase sediment from the Ochlockonee River were not at levels that would impact most aquatic species, although lead may be of some concern. Toxicity testing with proper freshwater mussel surrogates will be required to futher examine this. From a trace element perspective, sediment quality in the Ochlockonee River appears to be within acceptable limits for aquatic life. However, as in the case of water chemistry, sediment toxicity and sediment chemistry needs to be better delineated for tributaries and the river reach extent to further mussel recovery efforts.

Cumulatively, sites posing potential risk to riverine species achieved an estimated potential risk score of $\geq 5$ (below the dam, Little River, and $\sim 3$ miles SSE of Cairo, Georgia). These sites corresponded well with areas that no longer support their historic freshwater mussel populations. Conversely, sites with cumulative scores $<4$ were generally found in less impacted areas. Two sites where protected mussels have not recently been found had cumulative risk scores of 2 (second site below Lake Talquin) or 1 (uppermost northern sampling point NW of Thomasville, Georgia), respectively.

Acknowledgements. The US Fish and Wildlife Service (USFWS) recognizes the contributions of Kelly Huizenga, a USFWS Student Conservation Associate, and USFWS volunteer Jamie Ruddell for their assistance with sample collection and laboratory analyses. Additionally, many people have helped in the culmination of this report, but in particular we thank: Chris Ingersoll (USGS), Tom Augspurger (USFWS), Bill Starkel (USFWS), Kathy Hoffmaster (USFWS) and Gail Carmody (USFWS).

\section{LITERATURE CITED}

American Public Health Association, American Water Works Association, and Water Environment Federation (1998) Standard methods for the examination of water and wastewater, 20th edn. American Public Health Association, Washington, DC

Augspurger T, Keller A, Black M, Cope W, Dwyer F (2003) Water quality guidance for protection of freshwater mussels (Unionidae) from ammonia exposure. Environ Toxicol Chem 22(11):2569-2575

Bailey LL, Simons TR, Pollock KH (2004) Estimating site occupancy and species detection probability parameters for terrestrial salamanders. Ecol Appl 14:692-702

Bogan AE (1993) Freshwater bivalve extinctions (Mollusca: Unionidae): A search for causes. Am Zool 33:599-609

Brouwer H, Murphy TP (1994) Diffusion method for the determination of acid-volatile sulfides (AVS) in sediment. Environ Toxicol Chem 13:1273-1275

Dahlberg ML, Shumway DL, Doudoroff P (1968) Influence of dissolved oxygen and carbon dioxide on swimming performance of lagemouth bass and coho salmon. J Fish Res Board Can 25: 49-70

Davies BF (1974) Loss-on-ignition as an estimate of soil organic matter. Soil Sci Soc Am Pro 38:150-151

Di Toro DM, Mahony JD, Hansen DJ, Scott KJ, Carlson AR, Ankley GT (1992) Acid volatile sulfide predicts the acute toxicity of cadmium and nickel in sediments. Environ Sci Tech 26:96-101

Dredged Material Management Plans (DMMP) (2001) Reporting ammonia LC50 data for larval and amphipod bioassays. DMMP clarification paper. Prepared by Lauran Cole Warner (US Army Corps of Engineers) for the DMMP agencies, Seattle, WA

Eisler R (1988) Lead hazards to fish, wildlife, and invertebrates: a synoptic review. US Fish and Wildlife Service, Biological Report 85 (1.14)

Florida Department of Environmental Protection (2001) Basin 
Status Report-Ochlockonee and St. Marks. Northwest District, Group 1 Basin

Fuller SLH (1974) Clams and mussels (Mollusca: Bivalvia). In: Hart CW Jr, Fuller SLH (eds) Pollution ecology of freshwater invertebrates. Academic Press, New York, p 215-273

Georgia Department of Natural Resources (2002) Ochlockonee River Basin Management Plan, Environmental Protection Division, Atlanta, GA

Goudreau SE, Neves RJ, Sheehan RJ (1993) Effects of wastewater treatment plant effluents on freshwater mollusks in the upper Clinch River, Virginia, USA. Hydrobiologia 252: 211-230

Havlik ME, Marking LL (1987) Effects of contaminants on naiad mollusks (Unionidae): a review. US Fish and Wildlife Service, Washington, DC, Resource Publication 164

Horne FR, McIntosh S (1979) Factors influencing distribution of mussels in the Blanco River of central Texas. Nautilus 94:119-133

Jacobson PJ, Farris JL, Cherry DS, Neves RJ (1993) Juvenile freshwater mussel (Bivalvia: Unionidae) responses to acute toxicity testing with copper. Environ Toxicol Chem 12:879-833

Keller AE (1993) Acute toxicity of several pesticides, organic compounds, and a wastewater effluent to the freshwater mussel, Anodonta imbecillis, Ceriodaphnia dubia, and Pimephales promelas. B Environ Contam Toxicology 51: 696-702

Keller AE, Ruessler DS (1997) The toxicity of malathion to unionid mussels: Relationship to expected environmental concentrations. Environ Toxicol Chem 16:1028-1033

Keller AE, Zam SG (1991) The acute toxicity of selected metals to the freshwater mussel, Anodonta imbecillis. Environ Toxicol Chem 10:539-546

Lasier PJ, Winger PV, Bogenrieder KJ (2000) Toxicity of manganese to Ceriodaphnia dubia and Hyalella azteca. Arch Environ Con Tox 38:298-304

Layzer JB, Gordon ME, Anderson RM (1993) Mussels: the forgotten fauna of regulated rivers. A case study of the Caney Fork River. Regulated Rivers: Research and Management 8:63-71

MacDonald DD, Ingersoll CG, Berger TA (2000) Development and evaluation of consensus-based sediment quality guidelines for freshwater ecosystems. Arch Environ Con Tox 39:20-31

Microbics Corporation (1992) Microtox Manual. Condensed protocols, basic test. Vol 3. Carlsbad, CA

Miller WP, Miller DM (1987) A micro-pipette method for soil mechanical analysis. Commun Soil Sci Plan 18:1-15

Mummert AK, Neves RJ, Newcomb TJ, Cherry DS (2003) Sensitivity of juvenile freshwater mussels (Lampsilis fasciola, Villosa iris) to total and un-ionized ammonia. Environ Toxicol Chem 22(11):2545-2553

Naimo TJ (1995) A review of the effects of heavy metals on freshwater mussels. Ecotoxicology 4:341-362

National Native Mussel Conservation Committee (1998) National strategy for the conservation of native freshwater mussels. J Shellfish Res 17:1419-1428

Nebeker AV (1972) Effects of low oxygen concentration on survival and emergence of aquatic insects. Trans Am Fish Soc 101: 675-679

Nebeker AV, Onjukka ST, Stevens DG, Chapman GA Dominguez SE (1992) Effects of low dissolved oxygen on survival, growth and reproduction of Daphnia, Hyalella and Gammarus. Environ Toxicol Chem 11(3):373-379

Neves RJ, Bogan AE, Williams JD, Ahlstedt SA, Hartfield PW (1997) Status of aquatic mollusks in the southeastern United States: A downward spiral of diversity. In: Benz

Editorial responsibility: William Wallace,

Staten Island, New York, USA
GW, Collins DE (eds) Aquatic fauna in peril: The southeastern perspective. Spec Publ 1. Southeast Aquatic Research Institute, Lenz Design and Communications, Decatur, GA

Newton TJ (2003) The effects of ammonia and freshwater unionid mussels. Environ Toxicol Chem 22(11):2543-2544

Newton TJ, Allran JW, O'Donnell JA, Bartsch MR, Richardson WB (2003) Effects of ammonia on juvenile unionids (Lampsilis cardium) in laboratory sediment toxicity tests. Environ Toxicol Chem 22:2554-2560

Richter BD, Braun DP, Mendelson MA, Master LL (1997) Threats to imperiled freshwater fauna. Conserv Biol 11: 1081-1093

SAS Institute Inc (1990) SAS/STAT user's guide, version 6, 4th edn. Cary, NC

Sprague JB (1963) Resistance of 4 freshwater crustaceans to lethal high temperature and low oxygen. J Fish Res Board Can 20:387-415

USEPA (US Environmental Protection Agency) (1986) Ambient water quality criteria for dissolved oxygen. Criteria and Standards Division. EPA 440/5-86-003. US Environmental Protection Agency, Washington, DC

USEPA (US Environmental Protection Agency) and US Army Corps of Engineers (1993) Guidance memorandum: technical panel recommendations concerning use of acute amphipod tests in evaluation of dredged material. Environmental Protection Agency Office of Oceans, Wetlands, and Watersheds, Environmental Protection Agency Office of Science and Technology, and Final Paper 6/15/02

USEPA (US Environmental Protection Agency) (1994) Methods for measuring the toxicity and bioaccumulation of sediment-associated contaminants with freshwater invertebrates. EPA 600/R-94/024, US Environmental Protection Agency, Office of Research and Development, Duluth, MN

USEPA (US Environmental Protection Agency) (2000) Methods for measuring the toxicity and bioaccumulation of sediment-associated contaminants with freshwater invertebrates, Second Edition. EPA/600/R-99/064, US Environmental Protection Agency, Office of Research and Development, Duluth, MN

USEPA (US Environmental Protection Agency) (2002) National recommended water quality criteria: 2002. EPA822-R-02-047, US Environmental Protection Agency, Office of Research and Development, Duluth, MN

US Fish and Wildlife Service (2003) Recovery Plan for Endangered Fat Threeridge (Amblema neislerii), Shinyrayed Pocketbook (Lampsilis subangulata), Gulf Moccasinshell (Medionidus penicillatus), Ochlockonee Moccasinshell (Medionidus simpsonianus), and Oval Pigtoe (Pleurobema pyriforme); and Threatened Chipola Slabshell (Elliptio chipolaensis), and Purple Bankclimber (Elliptoideus sloatianus). Atlanta, GA

Williams JD, Fuller SLH, Grace R (1992) Effects of impoundment on freshwater mussels (Mollusca: Bivalvia: Unionidae) in the main channel of the Black Warrior and Tombigbee rivers in western Alabama. Bull Ala Mus Nat Hist 13:1-10

Williams JD, Warren ML, Cummings KS, Harris JL, Neves RJ (1993) Conservation status of freshwater mussels of the United States and Canada. Fisheries 18:6-22

Winger PV, Lasier PJ, Jackson BP (1998) The influence of extraction procedure on ion concentrations in sediment pore water. Arch Environ Con Tox 35:8-13

Zumwalt DC, Dwyer FJ, Greer IE, Ingersoll CG (1994) A water-renewal system that accurately delivers small volumes of water to exposure chambers. Environ Toxicol Chem 13:13111314

Submitted: May 5, 2006; Accepted: July 15, 2006

Proofs received from author(s): August 7, 2006 